\title{
Three Early Academic Library Surveys
}

Earlier studies have cited the 1938 University of Georgia survey as the first independent academic library survey by outside experts. This paper reports on three earlier surveys-Williams College in 1915, Rutgers University in 1937, and Beloit College in 1938-that have not previously been cited in the library literature. Comments are made on the institution and its library at the time of the survey, on the surveyors-James Wyer, William Randall, and Errett McDiarmid-and on the content and technique of each of the surveys.

NOTE: This paper is based primarily on an examination of copies of the three surveys described. It was supplemented by personal information on the Rutgers University survey, based on nine years experience in that library, and on information supplied by Lawrence Wikander, librarian at Williams College, and H. Vail Deale, librarian of Beloit College. I would like to express my appreciation to those two librarians for their cooperation.

$\mathrm{T}$ HE LIBRARY SURVEY is now a well-established and effective tool of library administration. Since the mid-1930s, according to a review of Library Literature, at least thirty full-scale surveys by outside experts have been made in American college and university libraries, and unrecorded surveys would probably double that number. In addition to a number of articles dealing with one aspect or another of surveys, the past few years have seen the publication of two monographs dealing with library surveys and their effectiveness.

Dr. Stevens is Associate University Librarian in the University of Connecticut.
The first was E. Walfred Erickson's College and University Library Surveys, 1938-1952. ${ }^{1}$ This publication, based on the author's 1958 doctoral dissertation at the University of Illinois, is primarily a study of the effectiveness of the library survey as a means of improving library operations, and Erickson deals only briefly with the history of the academic library survey. He does indicate, however, that "the first university library survey by a team of outside experts as we know it today, according to Library Literature, was made in 1938 at the University of Georgia, which was followed within two years by the surveys of libraries of Indiana University, the University of Mississippi, and the University of Florida."2 In 1965 the School of Library Service at Columbia University hosted and cosponsored, with the Committee on Library Surveys of the Association of College and Research Libraries of ALA, a Conference on $\mathrm{Li}$ brary Surveys "to review present-day

${ }^{1}$ E. Walfred Erickson, College and University Library Surveys, 1938-1952 (Chicago: American Library Association, 1961. ACRL Monograph No. 25).

${ }^{2}$ Ibid., p. 3. 
knowledge in the conduct of surveys of various types of libraries." ${ }^{3}$ At that conference, which dealt comprehensively with surveys, Guy R. Lyle presented a short paper entitled "An Exploration into the Origins and Evolution of the Library Survey." 4 His purpose was "to select a half-dozen or so landmark surveys of the past hundred years, to summarize their accomplishments and methodology, to expose some of the undercurrents which were at work beneath the surface of librarianship, and to hint at the manner in which they affected or were influenced by, or simply provided the setting for, surveys and the development of the survey technique." In a paper of this kind and length, dealing with library surveys of all kinds in libraries of all types, less than two pages could be devoted to the university library survey and its history. Lyle, like Erickson, comments simply that, "The earliest of the institutional library surveys prepared by outside experts was the Report of a Survey of the University of Georgia Library, published by the ALA in 1939."6

In 1933 The Carnegie Foundation for the Advancement of Teaching arranged with Walter Crosby Eells, Professor of Education at Stanford University, to undertake a study which would "analyze and appraise the various surveys of higher education." 7 In this classic study, conducted during the academic year 1933-34, Professor Eells identified over five hundred studies, beginning with a survey of Oberlin in 1908, covering various aspects of American higher education. Many of these were national or state surveys including the surveys of li-

${ }^{3}$ Conference on Library Surveys. Columbia Uni-versity, 1965. Library Surveys (New York: Columbia University Press, 1967), p. vi.

4 Ibid., p. 3-22.

$\checkmark$ Ibid., p. 4.

Ibid., p. 14

${ }^{7}$ Walter Crosby Eells, Surveys of American Higher Education (New York: The Carnegie Foundation for the Advancement of Teaching, 1937), p. iii. braries by Works, ${ }^{8}$ Rosenlof, ${ }^{9}$ and Randall; ${ }^{10}$ but there were forty-nine printed and fifty mimeographed surveys of individual institutions, including both selfsurveys and those by outside experts. In twenty-two of the printed surveys special attention was given to the library, but these of course were not devoted solely to the library, and where outside experts were involved they were generally not librarians.

Given the nature and intent of their studies, it is not surprising that Erickson and Lyle cite the University of Georgia survey in 1938 as the first survey of an academic library by an outside expert. That survey was the first survey published by the American Library Association, thus giving it a stamp of authority, and as Lyle points out, it "contributed substantially to shaping the pattern of future university library surveys."11 It was a landmark and richly deserves the honor it has been accorded.

Given the scope and magnitude of Eell's study, however, it is surprising that he fails to cite what must certainly be the first survey of an American college library by an outside expert. That honor clearly belongs to James L. Wyer's printed Report on the Library of Williams College in 1915. There were, in actual fact, three separate library surveys conducted by outside library ex-

\footnotetext{
${ }^{8}$ George A. Works, College and University Library Problems: a Study of a Selected Group of Institutions Prepared for the Association of American Universities (Chicago: American Library Association, 1927). Sponsored by the Carnegie Corporation of New York and the Association of American Universities; covers eighteen colleges and universities in twelve states.

${ }^{\circ}$ George W. Rosenlof, Library Facilities of TeacherTraining Institutions (New York: Bureau of Publications, Teachers College, Columbia University, 1929. Teachers College Contribution to Education no. 347). Sponsored by the American Association of Teachers Colleges; covers 111 institutions.

${ }^{10}$ William M. Randall, The College Library: a Descriptive Study of the Libraries in Four-Year Liberal Arts Colleges in the United States (Chicago: American Library Association and the University of Chicago Press, 1932). Sponsored by the Carnegie Corporation of New York; covers 205 liberal arts colleges in fortythree states and the District of Columbia.

11 Conference on Library Surveys, op. cit., p. 15.
} 
perts prior to the 1938 University of Georgia survey. The two later, unpublished surveys, which took place after Eell's study, were one conducted by William M. Randall at Rutgers University in 1937 and one conducted by Errett W. McDiarmid at Beloit College in early 1938.

At this point in time a study of the effectiveness of these three surveys in improving library operations at those institutions would be of little value. Erickson has, in general, shown that the survey is an effective tool and, in any case, the passage of time would make it almost impossible to measure their effectiveness. There is also obviously no point in trying to emphasize their influence on the techniques of the library survey for the very fact that they have not been previously cited means that their influence was virtually nonexistent. They do deserve recognition and notice. It might be interesting, therefore, and perhaps constructive simply to treat them briefly as historical documents from a particular point in time and to examine each of them briefly as such.

\section{The 1915 Williams College LIBRARY SURVEY}

In 1915 Williams College was an undergraduate liberal arts college, with no graduate or professional schools, serving a student body of five hundred and a faculty and staff of seventy-five. The libraries of the college contained about 82,000 volumes and were adding between 2,000 and 3,000 volumes annually. John Adams Lowe, who was to be librarian of the Rochester Public Library from 1932 to 1952 , had resigned as librarian and submitted a final report which contained suggestions. As has often been the case in later surveys, it was undoubtedly Lowe's resignation and report and the need for a new librarian, combined with the obvious need for a new building, that prompted the Board of Trustees to employ James L. Wyer to conduct a survey of the Williams College Library.

In 1915 Wyer had been director of the New York State Library and the New York State Library School for seven years. Forty-six years old, he had, after a brief career as a bank cashier, served as an assistant in the Minneapolis Public Library for a short time prior to becoming a student at the New York State Library School and an assistant in the New York State Library in 1897. He received his BLS from that school in 1898 and his MLS in 1905. He was librarian and professor of bibliography at the University of Nebraska from 1898 to 1905, before returning, as reference librarian in the New York State Library and vice-director of the New York State Library School in 1906. He was president of the American Library Association in 1910-1911 and had written numerous articles on the academic library. He received his $\mathrm{PhD}$ from New York State College in 1919, but his book The College and University Library was not published until 1921. ${ }^{12} \mathrm{He}$ had already, however, contributed an eighteen-page chapter on "The College and University Library" to the first edition of the Manual of Library Economy published by the ALA in 1911. Utilizing the same simple definition as Erickson, ${ }^{13}$ there is no question but that Wyer in 1915 was extremely well qualified as a library expert.

His survey of the library situation at Williams College in $1915^{14}$ is an inter-

\footnotetext{
12 Who Was Who in America, v. 3, 1951-1960, p. 943.

${ }^{13}$ Erickson, op. cit., p. 14, "Webster's New International Dictionary defines the expert as 'one who has a special skill or knowledge in a particular subject, as a science or art, whether acquired by experience or study,' and it is this simple definition which will be
used in this study."

${ }^{14}$ James L. Wyer, "Report on the Library of Williams College," Williams College Board of Trustees,
Minutes, May 6, 1915, pp. 55-67.
} 
esting report which, in several ways, foresees the development of later surveys as manifested in the 1938 University of Georgia survey. After only a brief statement about the college and its setting, Wyer makes the following recommendations: (1) that an addition to the existing library building should be built to provide relief until the new library building, which the college authorities agree is needed, can be provided,15 (2) that more adequate salaries should be paid, and that, in particular, the librarian to be appointed should be paid a professional salary and be worth it; (3) that the local classification scheme should be abandoned in favor of "some established system which is already carefully formulated and for the use of which printed aids exist that immensely simplify the work of classification" 16 and that a careful plan for reclassification be worked out; (4) that "all the books owned by the college should be under library jurisdiction and care"17 with centralized control of acquisitions and with the division of book funds to be left to the discretion of the librarian; and (5) that some fairly detailed comments given on the new library building and its specifications should be considered.

While much of his report is devoted to the specifications for the new building and to the new librarian, his calls for reclassification using an established scheme and for centralized administration of the library are, indeed, forerunners of similar recommendations in many future academic library surveys.

It is, however, some of the comments made almost in passing that are of most interest today. Wyer comments, for example that, "The book funds now provide each year a comfortable and rea-

\footnotetext{
${ }^{15}$ The library at Williams College is now located in Stetson Hall, which was erected in 1922.

${ }^{16}$ Ibid., p. 60.

17 Ibid., p. 61 .
}

sonably adequate sum for books, binding and periodicals. Free from the necessity for the costly books and periodicals required for graduate and professional work, the present annual income should meet the needs of the college for books indefinitely." $18 \mathrm{He}$ also made these comments on the likely growth of the library:

Williams College library now has 82,000 volumes and is adding, or is able to add, 3,000 volumes per year, an increment which will tend to increase. It is likely that within the next fifty years 170,000 will be added. . . . There may be a question as to how large a satisfactory library for a college of this size ought to be. This is largely a matter of speculation, for no college library in this country has reached a point where it fails to need more books or where it feels that the removal or segregation of obsolete or worthless books will counterbalance the current additions. . . . $\mathrm{He}$ is a bold man who will say that 400,000 or 500,000 volumes in Williams College Library (figures which probably will be reached within the next century) are as many books as will ever be needed. ${ }^{19}$

This report, done at the time when the general academic survey itself was still a relatively new technique, is a remarkable document. If the dates, figures, and a few dated expressions were removed, it would be difficult to distinguish much of this report from a contemporary academic library survey. Even many of his remarks about the building program have a contemporary

${ }^{18}$ Ibid., p. 58. In 1914 that endowment amounted to $\$ 166,847.21$ and provided an income of $\$ 7,806.92$ for the period ending March 31, 1915. That same endowment today would (assuming a return of 6 per cent) provide an income of approximately $\$ 10,000$ annually; the Williams College Library expended $\$ 114,637$ for books, periodicals, and binding in $1967 / 68$.

10 Ibid., p. 62-63. Wyer, in this instance, was not far off. By 1968, a little over 50 years later, the Williams College Library had attained about 320,000 volumes. At the present growth rate of about 10,000 volumes a year, the library should reach 400,000 volumes by 1976 and 500,000 volumes by 1986 . 
ring to them. ${ }^{20}$ Wyer very perceptively points up the setting of the library in the institution and the community, analyzes the problems it faces, and makes sound recommendations to guide its future growth and development.

\section{The 1937 Rutgers University LIBRARY SURVEY}

In 1937 Rutgers University had approximately 2,100 undergraduates, 125 regular graduate students, and a faculty of 225. In 1932 a Graduate Faculty had been created to control and guide the growing graduate program, and in 1936 the Rutgers University Press was established. "As attention turned toward scholarly activity, a new appreciation of the need for improving the library developed. Adequate for the purpose of undergraduate instruction, with nearly 250,000 volumes, the library was housed in a building that had long since become crowded to capacity and was handicapped by inadequate staff and a minuscule book fund. Although many years were to pass before these grave problems could be solved, they were at least given recognition by those who foresaw that the growing emphasis on graduate instruction and research would require library facilities and resources vastly larger than those available."21

George A. Osborn began working in the library shortly before his graduation from Rutgers College in 1897 and remained to become librarian in 1907. In 1934 he prepared a report outlining the deficiencies in the building, the book fund, and the staffing. By 1937 little progress had been made. It was in this setting then that William Randall was employed to make a survey of the library.

${ }^{20}$ E.g., "Especially should there be, so far as possible in a building to be used by many persons, an atmosphere of privacy, of intimacy, of invitation. ..." p. 62 .

${ }^{21}$ Richard P. McCormick, Rutgers: A Bicentennial History (New Brunswick: Rutgers University Press, 1966 ). p. 240-41.
Randall, 38, was a professor at the University of Chicago Graduate Library School, and had been a faculty member there since 1929. He had received an $\mathrm{AB}$ from the University of Michigan in 1921 and an AM from that institution in 1924. Randall worked as a classifier in the University of Michigan library from 1923 to 1925 and then moved to Hartford, Connecticut, where he was an instructor in linguistics at the Kennedy School of Missions while working on a $\mathrm{PhD}$, which he received in 1929 from the Hartford Theological Seminary. The editor of Library Quarterly since its inception in 1931, Randall had written a number of articles on the college library, and had recently produced the first edition, with Frances L. D. Goodrich, of Principles of College Library Administration (Chicago: American Library Association and the University of Chicago Press, 1936). He was also the author of the descriptive study of college libraries mentioned above which was an outgrowth of the investigations made by and for the Advisory Group of College Libraries of the Carnegie Corporation of New York under the chairmanship of William W. Bishop..$^{22}$ There is no doubt that Randall was well qualified as a library expert.

Randall's survey resulted in a ninepage mimeographed report entitled "Report on the Library Situation at Rutgers University, November, 1937." About one-third of the report is devoted to a general statement of what a university library should be, beginning with the comment that "the library of a university has the general functions of acquiring and preserving accessibly the books required to meet the needs of the institution." 23 Randall made a number of specific recommendations for the improvement of the library situation at

\footnotetext{
${ }^{22}$ Who's Who in Library Service, 2d ed. (New York: H. W. Wilson Co., 1943), p. 445.

${ }^{23}$ William Randall, "Report on the Library Situation at Rutgers University, November, 1937," p. 1.
} 
Rutgers. These included: (1) the appointment of a professionally trained assistant, or associate librarian; (2) the amalgamation of the library of the New Jersey College for Women into the administrative structure of the University Library; (3) the elimination of the technical staff at that library and the centralization of technical processes in the Rutgers University library; (4) the addition of at least five professional staff members; (5) the payment of higher salaries in order to attract more competent and better-trained staff; (6) the erection of a new library building; ${ }^{24}$ (7) the need for additional book funds since "Rutgers has failed to provide a reasonably adequate sum for books during the past decade"; ${ }^{25}(8)$ the establishment of a single divided catalog, ${ }^{26}$ to be duplicated by photographic means for the library of the New Jersey College for Women, for the entire University collection.

Randall's general conclusion was that,

Rutgers University is a first class institution, with a long tradition of excellence, rendering an important service to its state and to the nation. Its library, which is one of the most important units in its educational and research apparatus, is considerably behind the remainder of the institution in plant, support, and personnel. Until this situation is corrected, the entire University suffers from an inadequate service at a vital point in its program. The University Administration will do well to make the library a major care and re-

\footnotetext{
24 Almost 20 years passed before a new central library building was opened at Rutgers University, in September 1956.

${ }^{25}$ Randall, op. cit., p. 6.

${ }_{28}$ "This step is contrary to standard library practice, and will certainly cause a protest from technicalminded individuals in the profession." Ibid., p. 9. Perhaps even more boldly Randall suggested that consideration be given to substituting a classified subject catalog for the alphabetic subject catalog. Neither a divided catalog nor a classified subject catalog has been established in the Rutgers University library. It might, incidentally, be noted that the library had been using the Library of Congress classification system for a number of years; hence the lack of a recommendation for reclassification.
}

sponsibility on its budget during the next years. ${ }^{27}$

From this standpoint in time the most interesting aspects of the report are the comments that Randall made, simply in passing, and a number of years before the general establishment of undergraduate libraries, on the function of the library of the New Jersey College for Women. Because of its geographical proximity to the Rutgers University library, Randall stressed the fact that the faculty of that college should rely on the Rutgers University library for its research needs and that their own library "should be . . . only a collegiate library concerned with furnishing book service to the undergraduates of the Women's College. As such, it should have a librarian fitted by experience, personality, and training to render skillful and sympathetic assistance to students. ... The book collection should be small-probably not larger than 25,000 to 40,000 volumes at any time."28

Done just prior to the time when the academic library survey was about to come into fruition, Randall's survey is, for that reason, not as remarkable as Wyer's survey of the Williams College library. Nevertheless it is a sound and sensible report, which represents a good analysis of the library situation at Rutgers in 1937, although perhaps too large a part of it is devoted to general comments on the function of a university library.

\section{The 1938 Beloit College Library SuRvey}

In 1938 Beloit College was an undergraduate liberal arts college serving a student body of about six hundred and

\footnotetext{
${ }^{27}$ Ibid., p. 9 .
}

${ }^{28}$ Ibid., p. 4. The collection of what is now the Douglass College Library was about 130,000 volumes in 1968. Randall's view of the size of a collection needed for undergraduate use seems unrealistic not only in terms of today's standards but even in view of Wyer's comments on the same topic in his survey at Williams College in 1915 quoted above. 
a teaching faculty of about fifty. The library contained over 92,000 volumes and was adding about 2,000 volumes annually. In an effort to upgrade the library the Library Committee of the college faculty undertook a survey of the library, retaining Errett W. McDiarmid as a consultant.

Of the three surveyors, McDiarmid was perhaps the least qualified as an expert at the time of the study here under discussion. Only 28 years old in 1937, he had received his BA in 1929, his MA in 1930 from Texas Christian University, and his $\mathrm{AB}$ in Library Science in 1931 from Emory University. After receiving his $\mathrm{PhD}$ from the University of Chicago Graduate Library School in 1934, McDiarmid had been librarian at Baylor University from 1934 to 1937. At the time of this survey he had just become an associate in the University of Illinois Library School. His later career included promotion to associate professor in the University of Illinois Library School and, from 1943 to 1951, McDiarmid was to be university librarian and director of the Division of Library Instruction at the University of Minnesota. Although his book The Library Survey was not published until 1940, McDiarmid had already published a number of articles on various aspects of the academic library. ${ }^{29}$

The earlier surveys conducted by Wyer and Randall are the product of those two men's casual, often almost superficial, overview of institutions and their libraries. While both report that they discussed the library with a variety of administrative officers, faculty, and library staff (but not students), their reports reflect only their own thoughts and opinions.

McDiarmid's twenty-four page mimeographed report on the Beloit College 1461.

${ }^{20}$ Who's Who in America, v. 35, 1968-1969, p.
Library, ${ }^{30}$ on the other hand, is more nearly a forerunner on the "modern" survey in technique. He worked very closely with faculty and students, had detailed questionnaires prepared, completed, and tabulated, and reported faculty and student opinion of the library and of its strengths and weaknesses. To a large degree McDiarmid was only the director of "a cooperative venture on the part of administration, faculty, students, and library staff." 31

The faculty were asked to indicate, using checklists, what library services they used, what new services they would like to see the library staff provide, and how they encouraged effective use of the library. Students were asked to answer a variety of questions about their use, or nonuse, of the library, and their degree of satisfaction, or dissatisfaction, with it. In addition, a checklist of 1,000 titles was constructed, largely from the ALA Booklist Books for 1932 to 1936 , and checked against the Beloit library holdings.

Most of McDiarmid's comments are based on the tabulations of those formal questionnaires and checklists. The recommendations that he made stemming directly from those sources of information were: (1) that special consideration be given to library resources in three specific subject fields; (2) that a systematic attempt be made to improve the general collection of the library; and (3) that additional trained staff be made available. In addition, McDiarmid made some comments based on his own background, experience, and observations. These included his recommendations, first for a new library building, or failing that, extensive redecoration of the existing building, and second, for an increase in the budget.

\footnotetext{
${ }^{30}$ Errett W. McDiarmid "Report of a Survey of Beloit College Library" (mimeographed report dated March 29, 1938).

${ }^{31}$ Ibid., p. 1.
} 
Although not directly apparent in his recommendations, the most interesting aspect of McDiarmid's survey is his comment on the general adequacy of the Beloit College library and his views on what a good library should be. He began by indicating that the goal which the college has recently set for itself "by direct implication, presupposes an efficient and up-to-date college library." 32 His analysis of the responses to the faculty questionnaire was that they realized quite clearly the need for strong collections, individualized service for the faculty, and training of students in library use, but that the library was missing that mark. His chief criticism was that "the library has made its resources available when requested." ${ }^{33}$ His summary of the situation was that:

1. The library has not been the active instructional force that it must be to serve Beloit effectively.

2. The library has not served the faculty to the extent that the faculty expect and desire.

3. There appears to be a high degree of faculty effort in stimulating library use beyond required reading with satisfactory results.

4. General reading deserves more emphasis, in actual amount being, at present, very low. ${ }^{34}$

McDiarmid was quite clear in emphasizing the role of the library as an instructional device and in indicating that the primary deficiency of the Beloit College library was its inability effectively to fill that role. The technical and administrative aspects of the library's operation were of little or no concern to McDiarmid. Even his comments on a new building ("a college workshop planned for student and faculty use") or redecoration of the existing building ("to provide better lighting and more

32 Ibid.

${ }^{3}$ Ibid., p. 6.

34 Ibid., p. 14. attractive surroundings") ${ }^{35}$ reflect this interest. This report is a very strong statement of what is now called the library college idea and obviously owes much to the thinking of B. Lamar Johnson and Harvie Branscomb.

\section{Conclusion}

These three surveys represent the earliest independent approaches to the academic library survey. Each is interesting, but each is incomplete. Although Wyer comes remarkably close, no one of them adequately covers all of the components of the good university library as outlined by Louis R. Wilson in his preparations for the 1938 University of Georgia Library Survey. ${ }^{36}$ Nor does any one of them approach the present concept and detail of the methodology of the academic library survey as outlined by Tauber. ${ }^{37}$ They were the tentative beginnings of an approach to the improvement of library operations that has subsequently flourished and become a major tool. It is somewhat heartening to see how far the technique has developed. However, it is somewhat disheartening to see that the same basic individual library problems that faced Williams in 1915, Rutgers in 1937, and Beloit in 1938, remain, and that little progress has been made in solving them on a broad scale.

${ }^{35}$ Ibid., p. 21.

se "These related to collections adequate for carrying out the objectives of the university, a staff large enough and sufficiently well trained to afford a high level of library service, materials effectively organized, a good physical plant and modern equipment, close library integration with the administrative and educational policies and practices of the university, regional library resources, and adequate library finances.” Conference on Library Surveys, op. cit., p. 14. ${ }^{37}$ Maurice F. Tauber, "Surveys by Librarians," CRL, XV (April 1954), 188-96. See especially the section "Methodology," p. 193-95, which describes in detail the procedure Tauber and Jesse used in their survey of the Virginia Polytechnic Institute Library in 1949. The following passage gives some idea of the detail, "Use of an ediphone made it possible to transcribe materials from confidential reports and interviews. Approximately 20 cylinders of material were recorded before the surveyors left the campus" (p. 194). 